\title{
Moderating Role of Social Support on the Associations between Individual Level Factors and Depressive Symptoms in Young Adults in Guyana and Trinidad and Tobago
}

\author{
JL Roopnarine ${ }^{1}$, Y Wang ${ }^{2}$, A Krishnakumar ${ }^{1}$
}

\begin{abstract}
Objective: To determine the moderating role of different forms of support on the associations between active coping, stress, and life satisfaction and depressive symptoms.

Methods: Using a cross-sectional design, 194 mostly Indo Guyanese and 189 young adults from diverse ethnic groups in Trinidad and Tobago filled out a life satisfaction scale, a perceived stress scale, a social support scale, an active coping scale, and the Centre for Epidemiologic Studies of Depression Scale (CES-D).

Results: Young adults in Guyana showed a lower prevalence (36.6\%) of depression than those in Trinidad and Tobago (46\%). Stress and life satisfaction predicted depressive symptoms and family support mediate and moderated the association between young adults' life satisfaction and depressive symptoms in both countries.

Conclusion: In countries with challenging ecological niches and underdeveloped mental health systems, there should be greater emphasis on the moderating and mediating role of family support systems and life events in interventions focussing on common mental health problems.
\end{abstract}

Key words: Depression, family support, stress

\section{EI Papel Moderador del Apoyo Social en las Asociaciones Entre Factores de Nivel Individual y los Síntomas Depresivos en Adultos Jóvenes en Guyana y Trinidad y Tobago

\author{
JL Roopnarine ${ }^{1}$, Y Wang ${ }^{2}$, A Krishnakumar ${ }^{1}$
}

\begin{abstract}
RESUMEN
Objetivo: Determinar el papel moderador de las diferentes formas de apoyo en las asociaciones entre la satisfacción de afrontamiento, el estrés y la vida activa y los síntomas-depresivos.

Métodos: Usando un diseño transversal, 194 adultos en su mayoría indo-guyaneses, y 189 jóvenes de diversos grupos étnicos en Trinidad y Tobago, llenaron una escala de satisfacción de vida, una escala de estrés percibido, una escala de apoyo social, escala de afrontamiento activo, del Centro para Estudios Epidemiológicos de Escalas de Depresión (CES-D).

Resultados: Los adultos jóvenes de Guyana mostraron una menor prevalencia (36.6\%) de la depresión que los de Trinidad y Tobago (46\%). El estrés y la satisfacción con la vida predijeron síntomas depresivos, y el apoyo familiar moderó la asociación entre la satisfacción con la vida y los síntomas depresivos de los adultos jóvenes en ambos países.

Conclusión: En países con nichos ecológicos difíciles y sistemas de salud mental subdesarrollados, debe hacerse mayor énfasis en el papel moderador y mediador de los sistema de apoyo a




\section{la familia y los eventos de la vida en las intervenciones con problemas comunes de salud mental.}

Palabras claves: Depresión, apoyo de la familia, estrés

\section{INTRODUCTION}

Depression has been identified as a common mental health problem across the world $(1,2)$. Among young adults, it is associated with increased risk for attempted and completed suicides (3). Within the Caribbean, the prevalence of depression in the adult population varies across countries, and according to some reports, exceed those determined for developed and other developing societies $(4,5)$. To effectively address mental health service delivery in Caribbean countries, there is a greater need to understand the prevalence of nonpsychotic common mental health problems such as depressive symptoms, anxiety, and somatization and to determine factors that may moderate and mediate the associations between individual level functioning ( $e g$, stress and coping) and depressive symptoms in multi-ethnic communities at different stages of economic development.

Both Guyana and Trinidad and Tobago have multiethnic populations with sizeable numbers of East Indians who have elevated suicide rates compared to other ethnic groups in the Caribbean and Latin America (3). At the same time, Guyana has one of the highest poverty rates in the western hemisphere and a severely underdeveloped mental health system (6) and Trinidad and Tobago has been marred by crime and citizen insecurity (7). Because social support is linked to mental health outcomes in young adults and it is related to the onset and relapse of depression (8), it is possible that in difficult ecological niches such as those that exist in Guyana and Trinidad and Tobago, different forms of social support can assume a significant role in moderating the associations between individual level factors and life events and depressive symptoms. The goal of this study is to assess whether different levels and types of social support moderate the associations between stress, active coping, and life satisfaction and depressive symptoms in young adults in Guyana and Trinidad and Tobago.

\section{SUBJECTS AND METHODS}

The total sample consisted of 383 young adults from Guyana and Trinidad and Tobago. One hundred and ninety-four individuals (186 Indo-Guyanese; 47.9\% males; Mean age $=25.9$ years, $\mathrm{SD}=9.8$ years) were from the eastern county of Berbice in Guyana. Most (64.4\%) were single, $25.3 \%$ were married, and the rest were either in a long-term committed relationship (6\%) or separated/ divorced (4\%). Thirty-six per cent were high school graduates, $12 \%$ attended a Technical Institute, $17 \%$ attended Teacher's Training College, and 34\% were University students. Twenty-nine per cent enjoyed a high standard of living defined as always having enough to live comfortably and having nice things; $54 \%$ had a comfortable standard of living - occasionally having nice things but not always; $14 \%$ were just okay having enough for the necessities but not having many "extras"; and $10 \%$ barely got by or engaged in a constant struggle to make ends meet.

The sample from Trinidad and Tobago was heterogeneous $(\mathrm{n}=189 ; 56$ Indo-Trinidadians, 56 AfricanTrinidadians, 72 individuals of Mixed-ethnic ancestry; $42.3 \%$ males; Mean age $=25.7$ years, $\mathrm{SD}=9.1$ years ) and drawn from the northern part of Trinidad. Again, most of the adults were single (67.2\%), 18\% were married, and the rest were either in a long-term committed relationship or separated/divorced. Twenty-nine per cent were high school graduates, $14.8 \%$ attended a Technical Institute; 5.8\% attended Teacher's Training College; and 50\% were University students. Fourteen per cent enjoyed a high standard of living, $60 \%$ had a comfortable standard of living, 24\% were just okay, and 2\% barely got by. The study was reviewed by the Office of Research Integrity and Protections at Syracuse University and followed the guidelines for the conduct of research outlined by the American Psychological Association.

\section{Measures}

Centre for Epidemiologic Studies of Depression Scales (CES-D). The 20-item Centre for Epidemiologic Studies of Depression Scale [CES-D] (9) was deemed appropriate for measuring depressive mood because of its wide use with general populations. It measures depressive symptoms in nine groups: sadness (dysphoria), loss of interest (anhedonia), appetite, sleep, thinking/concentration, guilt (worthlessness), tired (fatigue), movement (agitation), and suicide ideation. A score of 16 indicates a subthreshold for depression whereas a score of below 16 
on all 20 items is of no clinical significance (9). The internal consistency was good (Cronbach's alpha $=0.88$ for Guyana and 0.88 for Trinidad and Tobago).

Stress. The Perceived Stress Scale (PSS) was used to assess stress (10). Factor analysis on the 10-item Likerttype scale $(0=$ never to $4=$ very often $)$ revealed that six of the 10 items loaded on a single factor. A mean score was calculated with higher scores indicating a higher level of perceived stress. The internal consistency of the scale in previous studies (10) was adequate (0.75) and good in this study (Cronbach's alpha $=0.86$ for Guyana; Cronbach's alpha $=0.84$ for Trinidad). Life Satisfaction. The Satisfaction with Life Scale (SWLS) was administered to obtain a global measure of life satisfaction (11). This 5-item Likert-type scale (1 = strongly disagree to $7=$ strongly agree) provides a general index of life satisfaction without measuring other constructs such as loneliness or positive affect. The item total correlations for the five items in prior work were $0.81,0.63,0.61,0.75$ and 0.66 (11). Factor analysis indicated that all five items loaded on a single factor to form a unidimensional scale. A mean score was calculated with higher scores indicating higher levels of life satisfaction. The internal consistency for the scale was good: Cronbach's alpha $=0.83$ for Guyana; Cronbach's alpha $=0.86$ for Trinidad and Tobago.

Active Coping. To gather information on active coping, we relied on the 12-item Likert-type $(1=$ completely false to $5=$ completely true) John Henryism Scale initially developed to assess self-determination, hard work, personal competence and environmental mastery (12). Factor analysis revealed that all 12 items loaded on the single construct of active coping. The Cronbach's alphas were: 0.76 for Guyana and 0.75 for Trinidad and Tobago.

Social Support. The Multidimensional Scale of Perceived Social Support (MSPSS) was used to determine different types and levels of social support (13). This 12 -item Likert-type scale $(1=$ very strongly disagree to $7=$ very strongly agree) assesses social support from three sources: family (4 items), significant others (4 items), and friends (4 items). Factor analysis showed that all four items loaded properly for their corresponding factor. The Cronbach's alphas for family support (0.80 Guyana, 0.86 Trinidad and Tobago), support from friends (0.89 Guyana, 0.90 Trinidad and Tobago), and significant others (0.90 Guyana, 0.90 Trinidad and Tobago). Procedure. The first author sought permission from the heads of departments within different institutions and community agencies in the two countries before potential participants were approached. After approval was received from them, individuals were contacted and provided a brief description of the study. Each signed a consent form that stated that participation was totally voluntary and that he/she could withdraw from the study at any time. The questionnaires were distributed and collected by the first author and two other trained adults. Data were entered into SPSS22.0 and analysed using factor analysis and multiple regression.

\section{RESULTS}

Table 1 displays the means and standard deviations for the major variables used in the analyses. Young adults in Guyana showed a lower prevalence $(36.6 \%)$ of depression than those in Trinidad and Tobago (46\%).

Table 1: Descriptive statistics for main variables, Mean (SD)

\begin{tabular}{llcc}
\hline Variable & $\begin{array}{c}\text { Guyanese } \\
(\mathbf{n = 1 9 4 )} \\
\text { Mean SD }\end{array}$ & $\begin{array}{c}\text { Trinidadian } \\
(\mathbf{n}=\mathbf{1 8 9}) \\
\text { Mean SD }\end{array}$ & $\begin{array}{c}\text { Total } \\
(\mathbf{n}=\mathbf{3 8 3})\end{array}$ \\
\hline Stress & $2.97(0.88)$ & $3.00(0.86)$ & $2.99(0.87)$ \\
Social support & & & \\
$\quad$ Significant others & $5.60(1.48)$ & $5.75(1.45)$ & $5.68(1.47)$ \\
$\quad$ Friends & $5.23(1.37)$ & $5.49(1.30)$ & $5.36(1.34)$ \\
$\quad$ Family & $5.60(1.17)$ & $5.19(1.44)$ & $5.50(1.34)$ \\
Active coping & $4.21(0.48)$ & $3.98(0.55)$ & $4.10(0.53)$ \\
Life satisfaction & $5.08(1.27)$ & $4.42(1.43)$ & $4.76(1.39)$ \\
Depression & $15.5(10.6)$ & $17.0(10.6)$ & $16.2(10.6)$ \\
& & &
\end{tabular}

To examine the associations between stress, active coping and social support and depressive symptoms, sociodemographic factors (educational attainment, marital status, gender and standard of living) were entered in Step 1 and individual level variables (active coping, life satisfaction, levels of support, and stress) were entered in Step 2 in the regression analyses. To assess the moderating role of social support, the different types of support were centered at the mean, interacted with stress, active coping and life satisfaction (14). Because of nonequivalence in sample characteristics and economic conditions between countries, separate models were run for the two groups.

For the Guyanese adults, in Step 1 the regression model explained $9 \%$ of the variance in depressive symptoms $F(6,187)=3.12, p<0.01$. Standard of living was positively associated with depressive symptoms $(\beta=0.24, p<0.01)$. In Step 2 , the model explained $51 \%$ of the variance in depressive symptoms $F(10,183)=19.06, p<0.001 ; F \Delta(4,183)=39.15, p<$ 0.001 . Stress $(\beta=0.50, p<0.01)$ was positively associated with and family support $(\beta=-0.25, p<0.01)$ 
and life satisfaction $(\beta=-0.20, p<0 \quad .01)$ were negatively associated with depressive symptoms. In Step 3, the interaction terms were entered and the nonsignificant interactions were dropped and the model was re-run $F(11,182)=17.96, p<0.001 ; F \Delta(1,183)=$ 3.92, $p<0.05$. Results from Step 3 indicated that the model explained $52 \%$ of the variance in depression. One interaction term was significant: family support*life satisfaction $(\beta=0.11, p<0.05)$.

For the Trinidad and Tobago sample, there were no significant ethnic differences on any of the measures listed in Table 1. Thus, the data for the three ethnic groups were combined for these analyses. In Step 1, the model explained $3 \%$ of the variance in depressive symptoms $F(5,183)=1.14, p>0.05$. In Step 2, the model explained $46 \%$ of the variance in depressive symptoms $F$ $(9,179)=16.67, p<0.001 ; F \Delta(4,179)=35.02, p<$ 0.001 . Stress $(\beta=0.50, p<0.01)$ was positively associated with and life satisfaction negatively associated with depressive symptoms $(\beta=-0.31, p<0.01)$. In Step 3, the interaction terms were entered and the non-significant interactions were dropped and the model was re-run $F(10,178)=15.58, p<0.001 ; F \Delta(1,179)=3.62, p=$ 0.059 . Results from Step 3 indicated that the model explained $47 \%$ of the variance in depressive symptoms. Again one interaction term was significant: family support*life satisfaction $(\beta=-0.11, p=0.059)$.

\section{DISCUSSION}

Despite disparity in economic conditions between Guyana and Trinidad and Tobago, Indo-Guyanese adults showed a lower prevalence of depression than a mixed ethnic sample in Trinidad and Tobago. The rates of depression in both countries were higher than those previously reported for individuals in Trinidad and Tobago (5, 6) but comparable to those of high school students in the Bahamas, Jamaica, St Kitts and Nevis, and St Vincent (15). The higher prevalence rate of depression in Trinidad and Tobago compared to Guyana could be due to sample characteristics, to higher rates of crime and citizen insecurity and dramatic differences in economic conditions within communities across countries. Alternatively, it may be an artifact of the instruments used to assess depressive symptoms across studies.

As in so many other communities across the world $(3,8)$, psychosocial factors were significant predictors of depressive symptoms in both countries. That is, stress was associated with higher levels of depressive symptoms, whereas greater satisfaction with life was associ- ated with lower levels of depressive symptoms. Active coping was not significantly linked to depressive symptoms. In developing societies such as Guyana and Trinidad and Tobago, active coping may not be heavily emphasized in addressing common mental health issues as in the developed world. Additionally, gender, educational attainment, marital status, and standard of living played negligible roles in predicting depressive symptoms in the two samples of young adults. This contradicts the findings of prior work in this area. It is possible that psychosocial factors may assume a far more central role in predicting depressive symptoms than sociodemographic characteristics in developing societies.

High levels of family support, in particular, appear to work jointly with life satisfaction to lower depressive symptoms for young adults in Guyana and Trinidad and Tobago. In countries with inadequate mental health infrastructure, family support could play a key role in developing prevention strategies that deter movement from depressive symptoms to suicide ideation and completion.

\section{CONCLUSION}

Because of the high rates of suicide among individuals of East Indian ancestry in Guyana and Trinidad and Tobago (3) and because of the association between depression and attempted and completed suicide $(3,8)$, greater attention should be given to factors within families that moderate and mediate their associations with stressful life events.

\section{ACKNOWLEDGEMENTS}

This study was supported by a grant from the Falk College at Syracuse University. We extend our gratitude to the individuals who assisted with and participated in the study.

\section{REFERENCES}

1. Prevalence, severity, and unmet need for treatment of mental disorders in the World Health Organization World Mental Health Surveys. JAMA 2004; 291: 2581-2590.

2. Abel WD, Gibson R, Hickling FW. Depression: A major public health problem facing the Caribbean. West Indian Med J 2005; 54: 353-354.

3. Preventing suicide: A global imperative. World Mental Health Organization. 2014.

4. Maharaj RG. Depression and the nature of Trinidadian family practice: A cross-sectional study. BMC Fam Prac 2007 8:25, doi: 10.1186/1471-2296-8-25.

5. Maharaj, RG, Reid SD, Misir A, Simeon DT. Depression and its associated factors among patients attending chronic disease 
clinics in Southwest Trinidad. West Indian Med J 2005; 54: 3693-74.

6. Sharpe J, Schafe S. Mental health in the Caribbean. In: Developmental, health, social, and clinical Psychology: Indigenous contributions to a global discipline in J L Roopnarine D Chadee eds. 2015, 305-325. Washington, DC: American Psychological Association.

7. UNDP Caribbean Human Development Report. Human development and the shift to better citizen security. 2012. Available at: http://hdr-caribbean.regionalcentrelac-undp.org/images/PDF/ caribbean_hdr2012.pdf.

8. Paykel ES. Life events, social support and depression. Acta Psych Scand, 23 AUG 2007 DOI: 10.1111/j.1600-0447.1994. tb05803.x.

9. Radloff LS. The CES-D scale self-report depression scale for research in the general population. App Psych Meas 1977; 1: 385401.
10. Cohen S, Williamson GM. Perceived stress in a probability sample of the United States in S Spacapan S Oskaap eds. The social psychology of health. 1988, 31-67, Newbury Park, CA: Sage

11. Diener E, Emmons RA, Laron RJ, Griffin S. Satisfaction with life scale. J of Pers Ass 1985; 49: 71-7-5.

12. James SA, Hartnett SA, Kalsbeek WD. John Henryism and blood pressure among Black men. J Behav Med 1983; 6: 259278.

13. Zimet DG, Dahlem NW, Zimeet SG, Gordon, K. The multidimensional scale of perceived social support. J of Person Ass 1988; 52: $30-41$.

14. Frazier PA, Tix AP, Barron KE. Testing moderator and mediator effects in counseling psychology research. J of Couns Psych 2004; 51: 115-134.

15. Lipps G, Lowe GA, Gibson RC, Halliday S, Morris A, Clarke N, Wilson RN. Parenting and depressive symptoms among adolescents in four Caribbean societies. Child \& Ado Psych \& Ment Heal 2012; 31 doi: 10.1 186/1753-2000-6-31. 